\title{
RENDIMIENTO DE VACAS LECHERAS DE BAJA PRODUCCIÓN EN CONDICIONES PASTORILES CON LA OFERTA DE AGUA DE BEBIDA SALADA O DESALINIZA- DA
}

\author{
Revelli, G. R. ${ }^{\prime} ;$ Sbodio, O. A. ${ }^{2}$; Gallardo, M. R. ${ }^{3}$; \\ VALTORTA, S. E. ${ }^{3,4}$ \& TERCERO, E. J. ${ }^{2}$
}

\begin{abstract}
RESUMEN
En la zona noroeste de la llamada Cuenca Lechera Central Argentina, se estudió el impacto de la calidad de agua para bebida en vacas Holando Argentino de baja producción $(<25 \mathrm{~kg} / \mathrm{d})$, alimentadas en condiciones pastoriles. Para el ensayo se utilizaron dos tratamientos: T1 agua subterránea con elevados niveles de salinidad y T2 agua desalinizada aplicando la tecnología de ósmosis inversa, los cuales contenían $\sim 10.000$ y $1.000 \mathrm{mg} / \mathrm{L}$ de Sólidos Disueltos Totales (SDT), respectivamente. No se encontraron diferencias significativas en la producción individual $(18,7 \mathrm{~kg} / \mathrm{d}$ para T1 vs. 18,6 $\mathrm{kg} / \mathrm{d}$ para T2) $(P>0,05)$. En el análisis de la composición de pooles de leche por tratamiento, se observó una diferencia significativa en el contenido de la Grasa Butirosa, con un aumento del 8,5 $\%$ a favor de las vacas que consumieron agua desalinizada (3,01\% para T1 vs. 3,26 \% para T2) $(P$ $<0,05)$. Esto determinó un incremento significativo de un 2,6\% en el nivel de los Sólidos Totales $(11,78 \%$ para T1 vs. $12,09 \%$ para T2) $(P<0,05)$. Los resultados indican que el exceso de salinidad del agua para bebida podría afectar negativamente la composición de la leche.

Palabras clave: vacas lecheras, agua de bebida, salinidad, ósmosis inversa, producción y composición de leche.
\end{abstract}

\section{SUMMARY}

\section{Performance of low producing grazing dairy cows conditions offered salty or desalinized drinking water.}

In the northwest zone of the so called Cuenca Lechera Central Argentina, the impact of drinking water quality on low producing Holstein cows $(<25 \mathrm{~kg} / \mathrm{d})$, under grazing conditions, was studied. For the trial itself two treatments were used: T1 groundwater with high levels of salinity and T2 desalinized water applying the inverse osmosis technology, which they contained $\sim 10,000$ and

1.- Laboratorio Integral de Servicios Analíticos (L.I.S.A.), Cooperativa Tambera Nueva Alpina Ltda. (S2340ALB) Ceres, provincia de Santa Fe, Argentina. e-mail: lisa@inthersil.com.ar 2.- Instituto de Tecnología de Alimentos (I.T.A.), Facultad de Ingeniería Química, Universidad Nacional del Litoral. C. C. 266. (3000) Santa Fe.

3.- Estación Experimental Agropecuaria Rafaela, INTA. C. C. 22. (2300) Rafaela, provincia de Santa Fe.

4.- Consejo Nacional de Investigaciones Científicas y Técnicas (CONICET), Argentina.

Manuscrito recibido el 8 de junio de 2005 y aceptado para su publicación el 10 de octubre de 2005. 
$1,000 \mathrm{mg} / \mathrm{L}$ of Total Dissolved Solids (TDS), respectively. No significant differences were found in the individual production $(18.7 \mathrm{~kg} / \mathrm{d}$ for T1 vs. $18.6 \mathrm{~kg} / \mathrm{d}$ for T2) $(P>0.05)$. When analyzing the composition of pooled milk per treatment, a significant difference in the milk Fat content was observed, with an increase of the $8.5 \%$ in favour of the cows that consumed desalinized water $(3.01$ $\%$ for T1 vs. $3.26 \%$ for T2) $(P<0.05)$. This determined a significant increment of a $2.6 \%$ in the level of the Total Solids $(11.78 \%$ for T1 vs. $12.09 \%$ for T2) $(P<0.05)$. The results indicate that drinking water salinity could affect negatively the milk composition.

Key words: dairy cows, drinking water, salinity, inverse osmosis, milk production and composition. 